\title{
IDENTIFICATION OF RESISTANT GENOTYPES CONSIDERING POLYGENIC SYSTEMS IN HOST-PATHOGEN INTERACTION
}

\author{
Leonardo Cunha Melo and João Bosco dos Santos
}

\begin{abstract}
Plant resistance to pathogens is the most efficient form of disease control. However, identification of resistant genotypes is often difficult, especially when the genetic basis for the host-pathogen relationship is unknown. This study was carried out to test a methodology capable of providing, in a simple way, information about host vertical and horizontal resistance as well as pathogen virulence. A simulation using twenty, ten, and five pathogen races and twenty hosts was carried out. Host reaction was controlled by ten genes with two alleles each. Eight genes had little effects, one had medium and the other strong effects. Genetic control of pathogenicity was identical to that of the host. Only homozygous genotypes were used for pathogens and hosts in this simulation, with no epistatic effects. Simulation was based on the expected disease severity with the inoculation of twenty hosts with twenty pathogen races, according to additive and interactive models proposed by Parlevliet and Zadoks (Euphytica 26: 5-21, 1977). Data were analyzed by model IV of Griffing, using a partial diallel scheme. A high correlation was found between general reaction ability (GRA) and potential host resistance, which proved to be an indicator of horizontal resistance. A high correlation between general aggressivity ability (GAA) and potential pathogenicity of the race also proved to be an aggressivity indicator. Specific interaction ability (SIA) is an indicator of host vertical resistance and pathogen virulence. Simulation with a lower number of races (ten and five) showed similar results. SIA was significant in both the interactive and additive models.
\end{abstract}

\section{INTRODUCTION}

Diseases are among the greatest causes of yield reduction in major crops. Control by plant resistance is the most desirable method, mainly because it does not increase production costs and also helps lessen environmental pollution. However, identification of resistant genotypes is often difficult, due to lack of knowledge of host-pathogen relationships and the type of genetic control of the host reaction. Understanding the ways in which host resistance alleles interact with pathogen virulence alleles is fundamentally important for defining plant breeding strategies for resistance to phytopathogens.

Genetic control of polygenic resistance is controversial. One hypothesis differentiates genetic control of monogenic (gene for gene) from polygenic (additive) resistance (Vanderplank, 1968; Robinson, 1979). Another believes in integrated genetic control of both resistance types (Parlevliet and Zadoks, 1977; Nelson, 1978; Parlevliet, 1993). These authors believe that the gene for gene theory must be extended to polygenic resistance regardless of the gene effects intensity. Gene for gene interaction has been seen in various cases of monogenic resistance. Although little experimental evidence of gene for gene interactions has been reported for polygenes, a theoretical simulation may be perfomed. This study was set up to test a methodology that might, in a straightforward way, provide information about vertical (gene for

Departamento de Biologia, Universidade Federal de Lavras (UFLA), Caixa Postal 37, 37200-000 Lavras, MG, Brasil. Send correspondence to J.B.S. gene) and horizontal resistance of host and pathogen aggressivity and virulence (gene for gene), in cases of polygenic interactions.

\section{METHODOLOGY}

The simulation study considered the host-pathogen polygenic interaction models described by Parlevliet and Zadoks (1977). Additive and interactive models were used, where host reaction and pathogenicity were controlled by ten genes. These genes were divided into three categories: eight with small, one with medium and one with large effects. Both, host and pathogen were considered diploid. The existence of only two alleles was assumed - one favorable (disease severity reduced in the host, and pathogenicity potential increased in the pathogen) and the other unfavorable (disease severity increased in the host and pathogenicity potential reduced in the pathogen). Only homozygous pathogens and hosts were considered in this simulation, with no epistatic effects.

The favorable allele (in homozygosis) of the gene with large effect has a resistance potential of $40 \%$ in the host, which results in $60 \%$ severity of the disease. The favorable allele (in homozygosis) of the medium effect gene has a resistance potential of $20 \%$ in the host, which results in $80 \%$ severity of the disease. The favorable allele (in homozygosis) for each small effect gene has 5\% of potential resistance and, consequently, 95\% disease severity. A homozygous host with favorable alleles at the eight small effect loci has $40 \%$ resistance potential. Effects of pathogenicity genes in the pathogen are of the same magnitude as the host reaction genes. Thus, the fa- 
vorable allele (in homozygosis) of the gene with large effect in the pathogen provides a $40 \%$ pathogenicity potential of disease severity, the medium effect $20 \%$ and the small effect $5 \%$ each.

In order to study these two host-pathogen polygenic interaction models, twenty hosts and twenty different pathogen races were simulated. Genetic constitution of these 20 hosts and 20 pathogens was obtained from various combinations of the ten genes controlling host-pathogen interaction. Genetic constitutions of the 20 hosts and 20 patho-

Table I - Genetic constitution, host potential susceptibilities and pathogen potential pathogenicities of the genotypes.

\begin{tabular}{|c|c|c|}
\hline Genotypes & $\begin{array}{c}\text { Potential } \\
\text { susceptibilities }(\%)\end{array}$ & $\begin{array}{c}\text { Potential } \\
\text { pathogenicities }(\%)\end{array}$ \\
\hline 1. $\mathrm{GMP}_{1} \mathrm{P}_{2} \mathrm{P}_{3} \mathrm{P}_{4} \mathrm{P}_{5} \mathrm{P}_{6} \mathrm{P}_{7} \mathrm{P}_{8}$ & 0 & 100 \\
\hline 2. $\mathrm{gmp}_{1} \mathrm{p}_{2} \mathrm{p}_{3} \mathrm{p}_{4} \mathrm{p}_{5} \mathrm{p}_{6} \mathrm{p}_{7} \mathrm{p}_{8}$ & 100 & 0 \\
\hline 3. $\mathrm{Gmp}_{1} \mathrm{p}_{2} \mathrm{p}_{3} \mathrm{p}_{4} \mathrm{p}_{5} \mathrm{p}_{6} \mathrm{p}_{7} \mathrm{p}_{8}$ & 60 & 40 \\
\hline 4. $\mathrm{gMp}_{1} \mathrm{p}_{2} \mathrm{p}_{3} \mathrm{p}_{4} \mathrm{p}_{5} \mathrm{p}_{6} \mathrm{p}_{7} \mathrm{p}_{8}$ & 80 & 20 \\
\hline 5. $\mathrm{gmP}_{1} \mathrm{P}_{2} \mathrm{P}_{3} \mathrm{P}_{4} \mathrm{P}_{5} \mathrm{P}_{6} \mathrm{P}_{7} \mathrm{P}_{8}$ & 60 & 40 \\
\hline 6. $\mathrm{GmP}_{1} \mathrm{P}_{2} \mathrm{P}_{3} \mathrm{P}_{4} \mathrm{P}_{5} \mathrm{P}_{6} \mathrm{P}_{7} \mathrm{P}_{8}$ & 20 & 80 \\
\hline 7. $\mathrm{gMP}_{1} \mathrm{P}_{2} \mathrm{P}_{3} \mathrm{P}_{4} \mathrm{P}_{5} \mathrm{P}_{6} \mathrm{P}_{7} \mathrm{P}_{8}$ & 40 & 60 \\
\hline 8. $\mathrm{GMp}_{1} \mathrm{p}_{2} \mathrm{p}_{3} \mathrm{p}_{4} \mathrm{p}_{5} \mathrm{p}_{6} \mathrm{p}_{7} \mathrm{p}_{8}$ & 40 & 60 \\
\hline 9. $\mathrm{GmP}_{1} \mathrm{P}_{2} \mathrm{p}_{3} \mathrm{p}_{4} \mathrm{p}_{5} \mathrm{p}_{6} \mathrm{p}_{7} \mathrm{p}_{8}$ & 50 & 50 \\
\hline 10. $\mathrm{GmP}_{1} \mathrm{P}_{2} \mathrm{P}_{3} \mathrm{P}_{4} \mathrm{p}_{5} \mathrm{p}_{6} \mathrm{p}_{7} \mathrm{p}_{8}$ & 40 & 60 \\
\hline 11. $\mathrm{GmP}_{1} \mathrm{P}_{2} \mathrm{P}_{3} \mathrm{P}_{4} \mathrm{P}_{5} \mathrm{P}_{6} \mathrm{p}_{7} \mathrm{p}_{8}$ & 30 & 70 \\
\hline 12. $\mathrm{gmP}_{1} \mathrm{P}_{2} \mathrm{P}_{3} \mathrm{P}_{4} \mathrm{P}_{5} \mathrm{p}_{6} \mathrm{p}_{7} \mathrm{p}_{8}$ & 75 & 25 \\
\hline 13. $\mathrm{gMP}_{1} \mathrm{P}_{2} \mathrm{p}_{3} \mathrm{p}_{4} \mathrm{p}_{5} \mathrm{p}_{6} \mathrm{p}_{7} \mathrm{p}_{8}$ & 70 & 30 \\
\hline 14. $\mathrm{gMP}_{1} \mathrm{P}_{2} \mathrm{P}_{3} \mathrm{P}_{4} \mathrm{p}_{5} \mathrm{p}_{6} \mathrm{p}_{7} \mathrm{p}_{8}$ & 60 & 40 \\
\hline 15. $\mathrm{gMP}_{1} \mathrm{P}_{2} \mathrm{P}_{3} \mathrm{P}_{4} \mathrm{P}_{5} \mathrm{P}_{6} \mathrm{p}_{7} \mathrm{p}_{8}$ & 50 & 50 \\
\hline 16. $\mathrm{gmP}_{1} \mathrm{P}_{2} \mathrm{p}_{3} \mathrm{p}_{4} \mathrm{p}_{5} \mathrm{p}_{6} \mathrm{p}_{7} \mathrm{p}_{8}$ & 90 & 10 \\
\hline 17. $\mathrm{GMP}_{1} \mathrm{p}_{2} \mathrm{p}_{3} \mathrm{p}_{4} \mathrm{p}_{5} \mathrm{p}_{6} \mathrm{p}_{7} \mathrm{p}_{8}$ & 35 & 65 \\
\hline 18. $\mathrm{GMP}_{1} \mathrm{P}_{2} \mathrm{p}_{3} \mathrm{p}_{4} \mathrm{p}_{5} \mathrm{p}_{6} \mathrm{p}_{7} \mathrm{p}_{8}$ & 30 & 70 \\
\hline 19. $\mathrm{GMP}_{1} \mathrm{P}_{2} \mathrm{P}_{3} \mathrm{P}_{4} \mathrm{p}_{5} \mathrm{p}_{6} \mathrm{p}_{7} \mathrm{p}_{8}$ & 20 & 80 \\
\hline 20. $\mathrm{GMP}_{1} \mathrm{P}_{2} \mathrm{P}_{3} \mathrm{P}_{4} \mathrm{P}_{5} \mathrm{P}_{6} \mathrm{p}_{7} \mathrm{p}_{8}$ & 10 & 90 \\
\hline
\end{tabular}

$\mathrm{G}$ and $\mathrm{g}=\mathrm{Gene}$ of strong effect; $\mathrm{M}$ and $\mathrm{m}=$ gene of medium effect; $\mathrm{P}$ and $\mathrm{p}=$ gene of little effect; $\mathrm{G}, \mathrm{M}$ and $\mathrm{P}=$ favorable alleles; $\mathrm{g}, \mathrm{m}, \mathrm{p}=$ unfavorable alleles; all genotypes are homozygous. gens are identical, in gene number and the magnitude of their effects. Table I shows the genetic constitution of the 20 genotypes (host and pathogen) and their respective potential susceptibilities (host) and pathogenicities (pathogen).

The potential susceptibility of a genotype can be defined as the minimum of the disease showed by this genotype, that is, severity of the disease caused by a race without pathogenic alleles. Potential pathogenicity is defined as the maximum disease severity that can be added to the host by a race; in other words, the severity of the disease presented by the genotype with all the resistance alleles when inoculated with any race.

Disease severity was defined by the sum of the potential susceptibility with potential pathogenicity of the inoculated pathogen in the additive model, regardless of resistance and pathogenicity gene loci (Table II). Thus, the pathogens with alleles for any level of disease severity can, proportionally, reduce the host potential resistance and, consequently, increase disease severity. Thus, the final percentage of host resistance results from its potential resistance subtracted from the potential pathogenicity of the inoculated race, regardless of the reaction locus in the host and pathogenicity of the pathogen, that is, $100 \%$ minus the disease severity. Therefore, there is no gene for gene interaction in this model, since one pathogen has the same pathogenicity level for all hosts.

In the interactive model, disease severity is defined only by potential susceptibility when the pathogenicity genes are not located at the gene locus corresponding to the host resistance gene (Parlevliet and Zadoks, 1977), or by the sum of the potential susceptibility with the potential pathogenicity when the resistance and pathogenicity genes are located at a corresponding gene locus (Table II). Thus, pathogens are able to reduce the resistance potential (increase disease severity) of the host only in cases where the resistance and pathogenic alleles are situated in corresponding gene loci. Therefore, in this model there is gene for gene interaction, with one pathogen having different levels of pathogenicity depending on the host. It should be pointed out that in the additive model, when disease severity is above $100 \%$, it is considered as $100 \%$.

Table II - Disease severity (\%) of some host-pathogen interactions according to additive and interactive models.

\begin{tabular}{|ccccc|}
\hline \multirow{2}{*}{$\begin{array}{c}\text { Host } \\
\text { (potential susceptibilities) }\end{array}$} & Model & \multicolumn{3}{c|}{ Pathogen (potential pathogenicities) } \\
\cline { 3 - 5 } & & & & \\
& & 4-gMppppppp (20) & 8-GMppppppp (60) & 11-GmPPPPPPp (70) \\
\hline \multirow{2}{*}{ 4-gMppppppp (80) } & additive & $80+20=100$ & $80+60=100$ & $80+70=100$ \\
& interactive & $80+20=100$ & $80+20=100$ & $80+0=80$ \\
6-GmPPPPPPP (20) & additive & $20+20=40$ & $20+60=80$ & $20+70=90$ \\
& interactive & $20+0=20$ & $20+40=60$ & $20+70=90$ \\
19-GMPPPPppp (20) & additive & $20+20=40$ & $20+60=80$ & $20+70=90$ \\
& interactive & $20+20=40$ & $20+60=80$ & $20+60=80$ \\
\hline
\end{tabular}

For abbreviations see Table I. 
In practice, this value represents host death (Table II; interactions $4 \times 8$ and $4 \times 11$ ).

Genes with small effects appearing in the host and pathogen, regardless of their number, are considered to be located in the corresponding locus in the interactive model. Thus, virulence alleles with small effects always correspond with small effect resistance alleles in the host, and are only inexpressive when they are more numerous in the pathogen than in the host (Table II; interaction $19 \times 11$ ). However, in practice, other innumerable combinations could occur.

Inoculation of the 20 races was simulated on the 20 hosts, one race per host, totaling 400 combinations. Similarly three other inoculation schemes involving the 20 hosts were simulated: 1 - the first ten races from Table I; 2 - the last ten races from Table I, and 3 - the first five races from Table I. This variation in number of races was to check if results from inoculation of all races were similar to those obtained with the inoculation of only some races. Disease severity obtained with each inoculation was calculated according to the additive and interactive models.

The Griffing model IV (1956) was used for data analysis, with the partial diallel scheme described by Geraldi and Miranda Filho (1988). Originally, the partial diallel was proposed to assess the combining ability of parents placed in distinct groups, and the inferences made for each group. In the present study a modified version of this methodology was used. One group is formed by hosts and the other by pathogens. In the partial diallel, the general combining abilities of the parents in group I (GCA I), group II (GCA II) and the specific combining ability (SCA) are estimated. Taking the host $\mathrm{x}$ pathogen interactions, GCA I corresponds to the host GRA (general reaction ability), representing the genotype horizontal resistance, as it depends on the mean performance of the host in the inoculations with the different pathogen genotypes (races). This resistance, however, was expressed in all the inoculations, regardless of the pathogen genetic constitution. Similarly, GCA II corresponds to the pathogen GAA (general aggressivity ability) as it represents the mean pathogenicity of each race when used to inoculate all host genotypes. SCA corresponds to SIA (specific interaction ability) indicating interaction among components of the two groups. Thus, its estimates should represent the pathogen race virulence and also the vertical resistance of the host genotypes. The mathematical model proposed to analyze the host-pathogen polygenic interaction by partial diallel analysis is the following:

$$
\mathrm{Y}_{\mathrm{ij}}=\mu+\mathrm{r}_{\mathrm{i}}+\mathrm{a}_{\mathrm{j}}+\mathrm{s}_{\mathrm{ij}}
$$

where $Y_{i j}=$ disease severity shown by the ith host when inoculated with the $j$ th race; $r_{i}=$ effect of horizontal resistance of the ith host; $a_{j}=$ aggressivity effect of the jth race; $s_{i j}=$ effect of interaction between the ith host and the jth race, relative to the virulence effects of the jth race with vertical resistance of the ith host.

Table III shows the analysis of variance of a partial diallel cross involving host and pathogen race groups.

Correlation between the host GRA and severity potential was estimated. Similarly, correlation between the pathogen GAA and the potential susceptibility for the additive and interactive models was obtained, as well as correlation among the GRA in the $20 \times 20,20 \times 10$ and $20 \times$ 5 diallels.

A simulation study was also performed with a $15 \mathrm{x}$ 8 diallel, that consisted of only hosts and races which had all the results of the host-pathogen relationships with a maximum $100 \%$ disease severity, needing no adjustments.

\section{RESULTS AND DISCUSSION}

Tables IV and V show, respectively, the disease severity presented by each host submitted to inoculation with the various pathogen races under both additive and interactive models. All alleles in race 1 were favorable to pathogenicity and caused $100 \%$ disease severity in all hosts, regardless of their genetic constitution and (additive and interactive) model. All alleles in race 2 were unfavorable and allowed the manifestation of potential resistance in the hosts, corresponding to disease severity subtracted from 100. In the additive model, hosts with the same potential resistance suffered the same disease severity for all pathogen races, for example genotypes 7,8 and 10 . On the other hand, in the interactive model, hosts with the same potential resistance (7, 8 and 10) had different disease severities depending on the resistance alleles present in each host, according to Parlevliet and Zadoks (1977).

Diallel analyses for additive and interactive mod-

Table III - Analysis of variance of a partial diallel model.

\begin{tabular}{|lcccc|}
\hline Source of variation & d.f. & MS & F (random) & F (fixed) $)^{2}$ \\
\hline Treatments & $\mathrm{pq}-1$ & & & \\
GRA (horizontal resistance) & $\mathrm{p}-1$ & MS1 & MS1/MS3 & MS1/MSE \\
GAA(aggressivity) & $\mathrm{q}-1$ & MS2 & MS2/MS3 & MS2/MSE \\
SIA (interaction) & $(\mathrm{p}-1)(\mathrm{q}-1)$ & MS3 & MS3/MSE & MS3/MSE \\
Error & $\mathrm{m}$ & MSE & & \\
\hline
\end{tabular}

$p=$ Number of hosts; $q=$ number of races; $m=$ error degree of freedom (d.f.) of the analysis of variance. ${ }^{1} \mathrm{Host}$ and pathogen effects considering random effects, and ${ }^{2}$ fixed effects. 
Table IV - Disease severity (\%) of 20 hosts inoculated with 20 races of a pathogen, according to additive model.

\begin{tabular}{|c|c|c|c|c|c|c|c|c|c|c|c|c|c|c|c|c|c|c|c|c|}
\hline $\mathrm{H} / \mathrm{P}$ & 1 & 2 & 3 & 4 & 5 & 6 & 7 & 8 & 9 & 10 & 11 & 12 & 13 & 14 & 15 & 16 & 17 & 18 & 19 & 20 \\
\hline 1 & 100 & 0 & 40 & 20 & 40 & 80 & 60 & 60 & 50 & 60 & 70 & 25 & 30 & 40 & 50 & 10 & 65 & 70 & 80 & 90 \\
\hline 2 & 100 & 100 & 100 & 100 & 100 & 100 & 100 & 100 & 100 & 100 & 100 & 100 & 100 & 100 & 100 & 100 & 100 & 100 & 100 & 100 \\
\hline 3 & 100 & 60 & 100 & 80 & 100 & 100 & 100 & 100 & 100 & 100 & 100 & 85 & 90 & 100 & 100 & 70 & 100 & 100 & 100 & 100 \\
\hline 4 & 100 & 80 & 100 & 100 & 100 & 100 & 100 & 100 & 100 & 100 & 100 & 100 & 100 & 100 & 100 & 90 & 100 & 100 & 100 & 100 \\
\hline 5 & 100 & 60 & 100 & 80 & 100 & 100 & 100 & 100 & 100 & 100 & 100 & 85 & 90 & 100 & 100 & 70 & 100 & 100 & 100 & 100 \\
\hline 6 & 100 & 20 & 60 & 40 & 60 & 100 & 80 & 80 & 70 & 80 & 90 & 45 & 50 & 60 & 70 & 30 & 85 & 90 & 100 & 100 \\
\hline 7 & 100 & 40 & 80 & 60 & 80 & 100 & 100 & 100 & 90 & 100 & 100 & 65 & 70 & 80 & 90 & 50 & 100 & 100 & 100 & 100 \\
\hline 8 & 100 & 40 & 80 & 60 & 80 & 100 & 100 & 100 & 90 & 100 & 100 & 65 & 70 & 80 & 90 & 50 & 100 & 100 & 100 & 100 \\
\hline 9 & 100 & 50 & 90 & 70 & 90 & 100 & 100 & 100 & 100 & 100 & 100 & 75 & 80 & 90 & 100 & 60 & 100 & 100 & 100 & 100 \\
\hline 10 & 100 & 40 & 80 & 60 & 80 & 100 & 100 & 100 & 90 & 100 & 100 & 65 & 70 & 80 & 90 & 50 & 100 & 100 & 100 & 100 \\
\hline 11 & 100 & 30 & 70 & 50 & 70 & 100 & 90 & 90 & 80 & 90 & 100 & 55 & 60 & 70 & 80 & 40 & 95 & 100 & 100 & 100 \\
\hline 12 & 100 & 75 & 100 & 95 & 100 & 100 & 100 & 100 & 100 & 100 & 100 & 100 & 100 & 100 & 100 & 85 & 100 & 100 & 100 & 100 \\
\hline 13 & 100 & 70 & 100 & 90 & 100 & 100 & 100 & 100 & 100 & 100 & 100 & 95 & 100 & 100 & 100 & 80 & 100 & 100 & 100 & 100 \\
\hline 14 & 100 & 60 & 100 & 80 & 100 & 100 & 100 & 100 & 100 & 100 & 100 & 85 & 90 & 100 & 100 & 70 & 100 & 100 & 100 & 100 \\
\hline 16 & 100 & 90 & 100 & 100 & 100 & 100 & 100 & 100 & 100 & 100 & 100 & 100 & 100 & 100 & 100 & 100 & 100 & 100 & 100 & 100 \\
\hline 17 & 100 & 35 & 75 & 55 & 75 & 100 & 95 & 95 & 85 & 95 & 100 & 60 & 65 & 75 & 85 & 45 & 100 & 100 & 100 & 100 \\
\hline 18 & 100 & 30 & 70 & 50 & 70 & 100 & 90 & 90 & 80 & 90 & 100 & 55 & 60 & 70 & 80 & 40 & 95 & 100 & 100 & 100 \\
\hline 19 & 100 & 20 & 60 & 40 & 60 & 100 & 80 & 80 & 70 & 80 & 90 & 45 & 50 & 60 & 70 & 30 & 85 & 90 & 100 & 100 \\
\hline 20 & 100 & 10 & 50 & 30 & 50 & 90 & 70 & 70 & 60 & 70 & 80 & 35 & 40 & 50 & 60 & 20 & 75 & 80 & 90 & 100 \\
\hline
\end{tabular}

$\mathrm{H} / \mathrm{P}=$ Host-pathogen relationship.

Table V - Disease severity (\%) of 20 hosts inoculated with 20 races of a pathogen, accoding to interactive model.

\begin{tabular}{|c|c|c|c|c|c|c|c|c|c|c|c|c|c|c|c|c|c|c|c|c|}
\hline $\mathrm{H} / \mathrm{P}$ & 1 & 2 & 3 & 4 & 5 & 6 & 7 & 8 & 9 & 10 & 11 & 12 & 13 & 14 & 15 & 16 & 17 & 18 & 19 & 20 \\
\hline 1 & 100 & 0 & 40 & 20 & 40 & 80 & 60 & 60 & 50 & 60 & 70 & 25 & 30 & 40 & 50 & 10 & 65 & 70 & 80 & 90 \\
\hline 2 & 100 & 100 & 100 & 100 & 100 & 100 & 100 & 100 & 100 & 100 & 100 & 100 & 100 & 100 & 100 & 100 & 100 & 100 & 100 & 100 \\
\hline 3 & 100 & 60 & 100 & 60 & 60 & 100 & 60 & 100 & 100 & 100 & 100 & 60 & 60 & 60 & 60 & 60 & 100 & 100 & 100 & 100 \\
\hline 4 & 100 & 80 & 80 & 100 & 80 & 80 & 100 & 100 & 80 & 80 & 80 & 80 & 100 & 100 & 100 & 80 & 100 & 100 & 100 & 100 \\
\hline 5 & 100 & 60 & 60 & 60 & 100 & 100 & 100 & 60 & 70 & 80 & 90 & 85 & 70 & 80 & 90 & 70 & 65 & 70 & 80 & 90 \\
\hline 6 & 100 & 20 & 60 & 20 & 60 & 100 & 60 & 60 & 70 & 80 & 90 & 45 & 30 & 40 & 50 & 30 & 65 & 70 & 80 & 90 \\
\hline 7 & 100 & 40 & 40 & 60 & 80 & 80 & 100 & 60 & 50 & 60 & 70 & 65 & 70 & 80 & 90 & 50 & 65 & 70 & 80 & 90 \\
\hline 8 & 100 & 40 & 80 & 60 & 40 & 80 & 60 & 100 & 80 & 80 & 80 & 40 & 60 & 60 & 60 & 40 & 100 & 100 & 100 & 100 \\
\hline 9 & 100 & 50 & 90 & 50 & 60 & 100 & 60 & 90 & 100 & 100 & 100 & 60 & 60 & 60 & 60 & 60 & 95 & 100 & 100 & 100 \\
\hline 10 & 100 & 40 & 80 & 40 & 60 & 100 & 60 & 80 & 90 & 100 & 100 & 60 & 50 & 60 & 60 & 50 & 85 & 90 & 100 & 100 \\
\hline 11 & 100 & 30 & 70 & 30 & 60 & 100 & 60 & 70 & 80 & 90 & 100 & 55 & 40 & 50 & 60 & 40 & 75 & 80 & 90 & 100 \\
\hline 12 & 100 & 75 & 75 & 75 & 100 & 100 & 100 & 75 & 85 & 95 & 100 & 100 & 85 & 95 & 100 & 85 & 80 & 85 & 95 & 100 \\
\hline 13 & 100 & 70 & 70 & 90 & 80 & 80 & 100 & 90 & 80 & 80 & 80 & 80 & 100 & 100 & 100 & 80 & 95 & 100 & 100 & 100 \\
\hline 14 & 100 & 60 & 60 & 80 & 80 & 80 & 100 & 80 & 70 & 80 & 80 & 80 & 90 & 100 & 100 & 70 & 85 & 90 & 100 & 100 \\
\hline 16 & 100 & 90 & 90 & 90 & 100 & 100 & 100 & 90 & 100 & 100 & 100 & 100 & 100 & 100 & 100 & 100 & 95 & 100 & 100 & 100 \\
\hline 17 & 100 & 35 & 75 & 55 & 40 & 80 & 60 & 95 & 80 & 80 & 80 & 40 & 60 & 60 & 60 & 40 & 100 & 100 & 100 & 100 \\
\hline 18 & 100 & 30 & 70 & 50 & 40 & 80 & 60 & 90 & 80 & 80 & 80 & 40 & 60 & 60 & 60 & 40 & 95 & 100 & 100 & 100 \\
\hline 19 & 100 & 20 & 60 & 40 & 40 & 80 & 60 & 80 & 70 & 80 & 80 & 40 & 50 & 60 & 60 & 30 & 85 & 90 & 100 & 100 \\
\hline 20 & 100 & 10 & 50 & 30 & 40 & 80 & 60 & 70 & 60 & 70 & 80 & 35 & 40 & 50 & 60 & 20 & 75 & 80 & 90 & 100 \\
\hline
\end{tabular}

$\mathrm{H} / \mathrm{P}=$ Host-pathogen interaction.

els (Table VI) showed significance of GRA and GAA indicating the presence of variability for horizontal resistance in hosts and aggressivity in the pathogen races. The SIA significance, in both models, indicates existence of race $x$ host interactions in both cases, but with greater importance in the interactive model due to its larger variance. However, in the simulation carried out by Parlevliet and Zadoks (1977), the additive model is characterized by not showing this type of interaction. The basic difference between their simulation and this study is the elimination of cases where disease severity is greater than $100 \%$. Adjusting these cases for the maximum value of $100 \%$ creates an interaction among races and hosts. This happens because some more pathogenic races increase the disease severity in greater proportion in the more resistant hosts than in the less resistant. The less resistant (great potential susceptibility) hosts are already closer to the maximum severity of $100 \%$, resulting in unnecessary pathogenicity alleles, which therefore are not expressed in these hosts, but are expressed in resistance hosts where the potential 
susceptibility is lower. Thus, this adjustment results in different contributions of pathogens and hosts for disease severity in an inoculation, contributing to the significance of the host $\mathrm{x}$ pathogen interaction.

To prove this hypothesis, an analysis involving only hosts and races which had disease severity lower or equal to $100 \%$ without adjustment was carried out. Table VII shows that, in the additive model, the interaction effect was equal to zero, and in the interactive model, this interaction was significant as described by Parlevliet and Zadoks (1977). It became clear that there may be interaction among races and pathogen even in the additive model, since the existence of unnecessary genes in some racehost interactions shows the presence of a certain interaction level. This situation is, in practice, very common, as it would be difficult to find interaction without the existence of unnecessary genes.

Furthermore, all the variance (mean squares) and means of disease severity were always lower in the interactive model, agreeing with Parlevliet and Zadoks (1977). This is due to the gene for gene relationship in the interactive model which expresses the pathogenicity genes only if there is a reaction gene at the same gene locus. In the additive model all the pathogenicity genes express themselves regardless of their position, which leads to an increase in the disease variance and mean.

Table VIII shows the general reaction and aggressive abilities for the additive and interactive models, with 20 hosts and 20 races. These values correspond to the levels of pathogen aggressivity and horizontal resistance in the host. Genotype 1, which has all the resistance alleles, had the lowest GRA and therefore the greatest horizontal resistance, since the lower the disease severity, the more negative the host GRA and, therefore, the greater the resistance. For the pathogen, it was found that genotype 1, which had all the virulence alleles, had the greatest GAA relative to the greatest disease severity caused by this race. It was also observed that in the additive model genotypes with the same potential resistance $(3,5$ and $14 ; 7,8$ and $10 ; 9$ and $15 ; 6$ and 19;11 and 18) had the same horizontal resistance (GRA), which did not happen in the interactive model. In the additive model only potential resistance is important, regardless of the gene locus, while in the interactive model gene position is fundamentally important, due to gene for gene interaction. Thus, genotypes with the same potential resistance may have totally different horizontal resistances.

Correlation results (Table IX) for additive and interactive models between GRA and potential susceptibility, and pathogens GAA with potential pathogenicity show that GRA and the GAA adequately show host horizontal resistance and pathogen aggressivity, respectively. It is clear that genotypes with greater GRA (horizontal resistance) are those which had greater resistance potential. Similarly, pathogens with greater GAA (aggressivity) are those with greater pathogenicity potential.
Table VI - Diallelic analysis of disease severity showing mean square according to additive model (MSA) and interactive model (MSI) including 20 hosts and 20 races.

\begin{tabular}{|lrrr|}
\hline Source of variation & d.f. & \multicolumn{1}{c}{ MSA } & \multicolumn{1}{c}{ MSI } \\
\hline Treatments & 399 & 457.08 & 500.75 \\
GRA (horizontal resistance) & 19 & 3562.24 & 3201.95 \\
GAA(aggressivity) & 19 & 4406.97 & 4056.32 \\
SIA (interaction) & 361 & 85.76 & 171.50 \\
\hline Average disease severity & & 85.25 & 77.00 \\
\hline
\end{tabular}

Table VII - Diallelic analysis of disease severity (without adjustment) showing mean square according to additive model (MSA) and interactive model (MSI) including 15 hosts and 8 races.

\begin{tabular}{|lrrr|}
\hline Source of variation & d.f. & MSA & MSI \\
\hline Treatments & 119 & 515.67 & 488.36 \\
GRA (horizontal resistance) & 14 & 2699.05 & 2432.08 \\
GAA(aggressivity) & 7 & 3368.30 & 1440.21 \\
SIA (interaction) & 98 & 0.00 & 142.69 \\
\hline Average disease severity & & 61.95 & 55.71 \\
\hline
\end{tabular}

Table VIII - Estimates of general reaction ability (GRA) and aggressivity (GAA) according to additive and interactive models from 20 × 20 diallel.

\begin{tabular}{|c|c|c|c|c|}
\hline \multirow[t]{2}{*}{ Genotypes } & \multicolumn{2}{|c|}{ Additive model } & \multicolumn{2}{|c|}{ Interactive model } \\
\hline & GRA & GAA & GRA & GAA \\
\hline 1. $\mathrm{GMP}_{1} \mathrm{P}_{2} \mathrm{P}_{3} \mathrm{P}_{4} \mathrm{P}_{5} \mathrm{P}_{6} \mathrm{P}_{7} \mathrm{P}_{8}$ & -33.25 & 14.75 & -25.85 & 22.85 \\
\hline 2. $\mathrm{gmp}_{1} \mathrm{p}_{2} \mathrm{p}_{3} \mathrm{p}_{4} \mathrm{p}_{5} \mathrm{p}_{6} \mathrm{p}_{7} \mathrm{p}_{8}$ & 14.25 & -37.25 & 22.85 & -29.15 \\
\hline 3. $\mathrm{Gmp}_{1} \mathrm{p}_{2} \mathrm{p}_{3} \mathrm{p}_{4} \mathrm{p}_{5} \mathrm{p}_{6} \mathrm{p}_{7} \mathrm{p}_{8}$ & 9.00 & -3.00 & 4.85 & -7.15 \\
\hline 4. $\mathrm{gMp}_{1} \mathrm{p}_{2} \mathrm{p}_{3} \mathrm{p}_{4} \mathrm{p}_{5} \mathrm{p}_{6} \mathrm{p}_{7} \mathrm{p}_{8}$ & 13.25 & -18.75 & 13.85 & -18.15 \\
\hline 5. $\mathrm{gmP}_{1} \mathrm{P}_{2} \mathrm{P}_{3} \mathrm{P}_{4} \mathrm{P}_{5} \mathrm{P}_{6} \mathrm{P}_{7} \mathrm{P}_{8}$ & 9.00 & -3.00 & 1.85 & -10.15 \\
\hline 6. $\mathrm{GmP}_{1} \mathrm{P}_{2} \mathrm{P}_{3} \mathrm{P}_{4} \mathrm{P}_{5} \mathrm{P}_{6} \mathrm{P}_{7} \mathrm{P}_{8}$ & -14.75 & 13.25 & -16.15 & 11.85 \\
\hline 7. $\mathrm{gMP}_{1} \mathrm{P}_{2} \mathrm{P}_{3} \mathrm{P}_{4} \mathrm{P}_{5} \mathrm{P}_{6} \mathrm{P}_{7} \mathrm{P}_{8}$ & 0.00 & 8.00 & -8.15 & 0.85 \\
\hline 8. $\mathrm{GMp}_{1} \mathrm{p}_{2} \mathrm{p}_{3} \mathrm{p}_{4} \mathrm{p}_{5} \mathrm{p}_{6} \mathrm{p}_{7} \mathrm{p}_{8}$ & 0.00 & 8.00 & -4.15 & 3.85 \\
\hline 9. $\mathrm{GmP}_{1} \mathrm{P}_{2} \mathrm{p}_{3} \mathrm{p}_{4} \mathrm{p}_{5} \mathrm{p}_{6} \mathrm{p}_{7} \mathrm{p}_{8}$ & 5.00 & 3.00 & 2.60 & 0.60 \\
\hline 10. $\mathrm{GmP}_{1} \mathrm{P}_{2} \mathrm{P}_{3} \mathrm{P}_{4} \mathrm{p}_{5} \mathrm{p}_{6} \mathrm{p}_{7} \mathrm{p}_{8}$ & 0.00 & 8.00 & -1.90 & 6.10 \\
\hline 11. $\mathrm{GmP}_{1} \mathrm{P}_{2} \mathrm{P}_{3} \mathrm{P}_{4} \mathrm{P}_{5} \mathrm{P}_{6} \mathrm{p}_{7} \mathrm{p}_{8}$ & -6.75 & 11.25 & -8.15 & 9.85 \\
\hline 12. $\mathrm{gmP}_{1} \mathrm{P}_{2} \mathrm{P}_{3} \mathrm{P}_{4} \mathrm{P}_{5} \mathrm{p}_{6} \mathrm{p}_{7} \mathrm{p}_{8}$ & 12.5 & -14.50 & 13.10 & -13.90 \\
\hline 13. $\mathrm{gMP}_{1} \mathrm{P}_{2} \mathrm{p}_{3} \mathrm{p}_{4} \mathrm{p}_{5} \mathrm{p}_{6} \mathrm{p}_{7} \mathrm{p}_{8}$ & 11.50 & -10.50 & 11.60 & -7.40 \\
\hline 14. $\mathrm{gMP}_{1} \mathrm{P}_{2} \mathrm{P}_{3} \mathrm{P}_{4} \mathrm{p}_{5} \mathrm{p}_{6} \mathrm{p}_{7} \mathrm{p}_{8}$ & 9.00 & -3.00 & 7.10 & -4.90 \\
\hline 15. $\mathrm{gMP}_{1} \mathrm{P}_{2} \mathrm{P}_{3} \mathrm{P}_{4} \mathrm{P}_{5} \mathrm{P}_{6} \mathrm{p}_{7} \mathrm{p}_{8}$ & 5.00 & 3.00 & 0.85 & -1.15 \\
\hline 16. $\mathrm{gmP}_{1} \mathrm{P}_{2} \mathrm{p}_{3} \mathrm{p}_{4} \mathrm{p}_{5} \mathrm{p}_{6} \mathrm{p}_{7} \mathrm{p}_{8}$ & 14.25 & -27.75 & 20.60 & -21.40 \\
\hline 17. $\mathrm{GMP}_{1} \mathrm{p}_{2} \mathrm{p}_{3} \mathrm{p}_{4} \mathrm{p}_{5} \mathrm{p}_{6} \mathrm{p}_{7} \mathrm{p}_{8}$ & -3.25 & 9.75 & -5.15 & 7.85 \\
\hline 18. $\mathrm{GMP}_{1} \mathrm{P}_{2} \mathrm{p}_{3} \mathrm{p}_{4} \mathrm{p}_{5} \mathrm{p}_{6} \mathrm{p}_{7} \mathrm{p}_{8}$ & -6.75 & 11.25 & -6.40 & 11.60 \\
\hline 19. $\mathrm{GMP}_{1} \mathrm{P}_{2} \mathrm{P}_{3} \mathrm{P}_{4} \mathrm{p}_{5} \mathrm{p}_{6} \mathrm{p}_{7} \mathrm{p}_{8}$ & -14.75 & 13.25 & -8.90 & 17.10 \\
\hline 20. $\mathrm{GMP}_{1} \mathrm{P}_{2} \mathrm{P}_{3} \mathrm{P}_{4} \mathrm{P}_{5} \mathrm{P}_{6} \mathrm{p}_{7} \mathrm{p}_{8}$ & -23.75 & 14.25 & -15.15 & 20.85 \\
\hline
\end{tabular}

For abbreviations see Table I. 
Table IX - Correlations between general reaction ability (GRA) and potential susceptibilities (P.S.) and between general aggressivity ability (GAA) and potential pathogenicities (P.P.) according to additive and interactive models.

\begin{tabular}{|c|c|c|c|c|}
\hline & \multicolumn{2}{|c|}{ Addive model } & \multicolumn{2}{|c|}{ Interactive model } \\
\hline & P.S. & P.P. & P.S. & P.P. \\
\hline GRA & $0.936 * *$ & - & $0.984 * *$ & - \\
\hline GAA & - & $0.950^{* *}$ & - & $0.989 * *$ \\
\hline
\end{tabular}

** Significant at $1 \%$ level of probability according to $t$-test.

Significance of SIA indicates interaction among races and hosts. SIA values can provide information about genotype vertical resistance as well as race virulence. SIA is significant because host horizontal resistance (GRA) and pathogen aggressivity (GAA) alone were not sufficient to explain the variation found. In this case, the host behaves differently when inoculated with a different race and viceversa. SIA values, therefore, are good indicators of specific host-race behavior. Thus, the behavior of a particular host or race of interest could be studied in more detail. A genotype which has a high horizontal resistance will certainly be infected by some more virulent races. A negative SIA value indicates that the genotype is more resistant to this specific race than expected based on the horizontal resistance of the genotype and the pathogen aggressivity. If the SIA is positive the contrary happens. There is a simi- lar performance in the pathogen. In the additive model, the SIA value is directly linked to the number of unnecessary genes present in the race $\mathrm{x}$ genotype interaction. Thus, the greater the adjustments of disease severity, the greater the SIA. In the additive model, hosts with the same resistance potential had the same SIA values for all the pathogen races, and races with the same pathogenicity potential also had the same SIA for all the hosts.

In the interactive model, SIA values depend on the correspondence of resistance and pathogenicity alleles at the various gene loci, due to the gene for gene interaction. Thus, in all situations where there is a level of gene for gene coincidence above or below the mean, there will be positive and negative SIA values, respectively. This is easily proven by the fact that, for all genotypes, the greatest positive SIA values were exactly for those where the genotypes that were inoculated by the race with pathogenic alleles situated at the same gene loci as the resistance alleles $(1 \times 1,2 \times 2,3 \times 3, \ldots, 20 \times 20)$. Thus, race 1 was the most virulent (greatest SIA) for genotype 1, race 2 for genotype 2 and so on. Figures 1 and 2 show this behavior for hosts $6,7,8,9$ and 10 in the additive model and 7,8 , and 10 in the interactive model, respectively, when inoculated with the 20 races. Hosts 7, 8 and 10, which had the same resistance potential (Table I), had identical SIA values for all races in the additive model (Figure 1), which did not occur in the interactive model (Figure 2). It was found that the hosts had different vertical resistance levels for the different races, making identification of the most virulent races

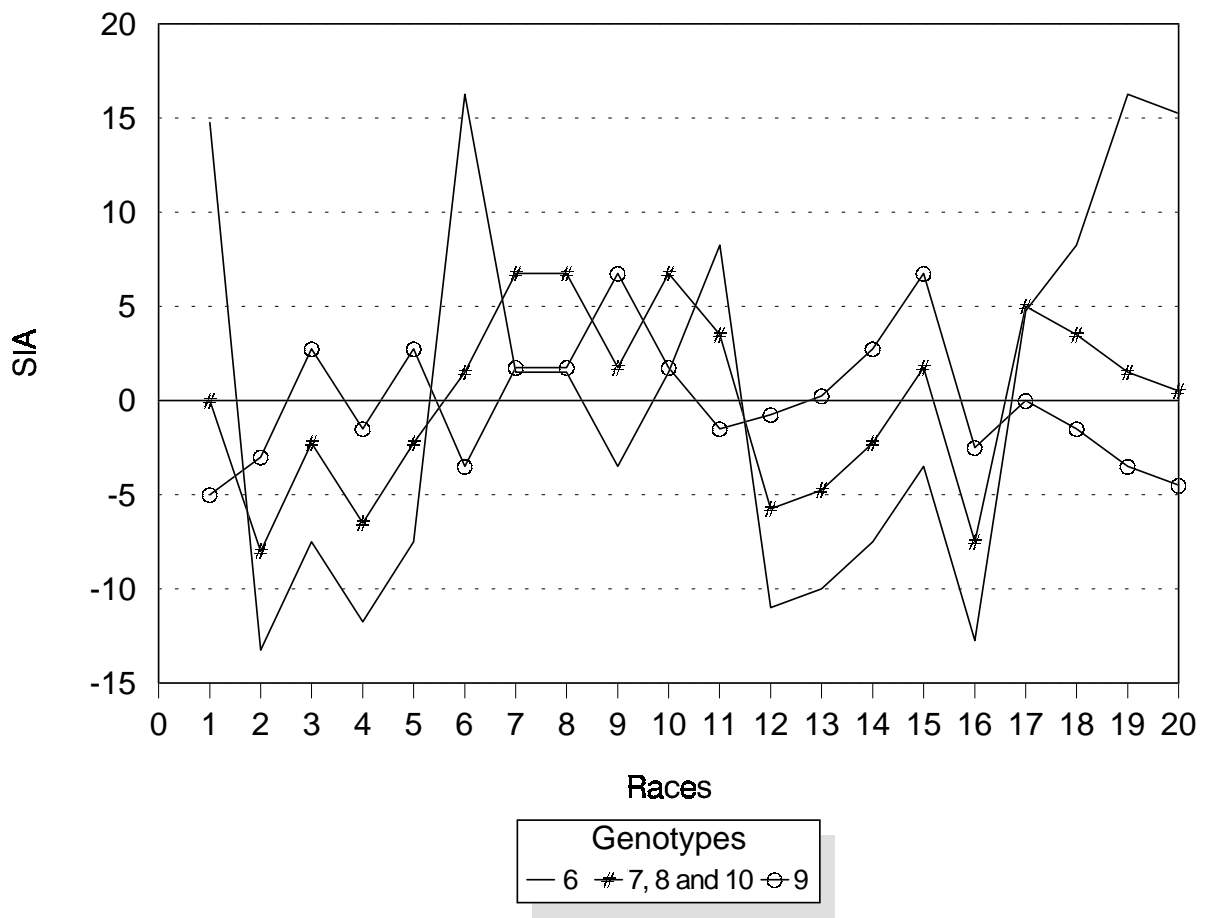

Figure 1 - Specific interaction ability (SIA) of some hosts inoculated with different pathogen races according to additive model. 
for each host easy. For example, in the interactive model host 7 has greater vertical resistance to race 3 , host 8 to 5 and host 10 to 13 , which helps in the selection of parents in a plant breeding program for controlling races with higher frequencies.

Figure 3 shows the reaction of host 15 to all the races. Race 15 is the most virulent to host 15 (as already mentioned) and race 3 the least virulent. Other highly virulent races such as 7 and 14 had genotypes similar to 15
(Table I). In a race frequency survey in a certain region, predominance of any of them is a good indicator for recommending the most resistant cultivars.

Simulations with different race numbers were carried out to see if it was necessary to inoculate with all races corresponding to the tested hosts, or if with only a sample it would be sufficient. For this purpose, the correlations among the horizontal resistance values (GRA) obtained from the $20 \times 20$ and the other diallels were esti-

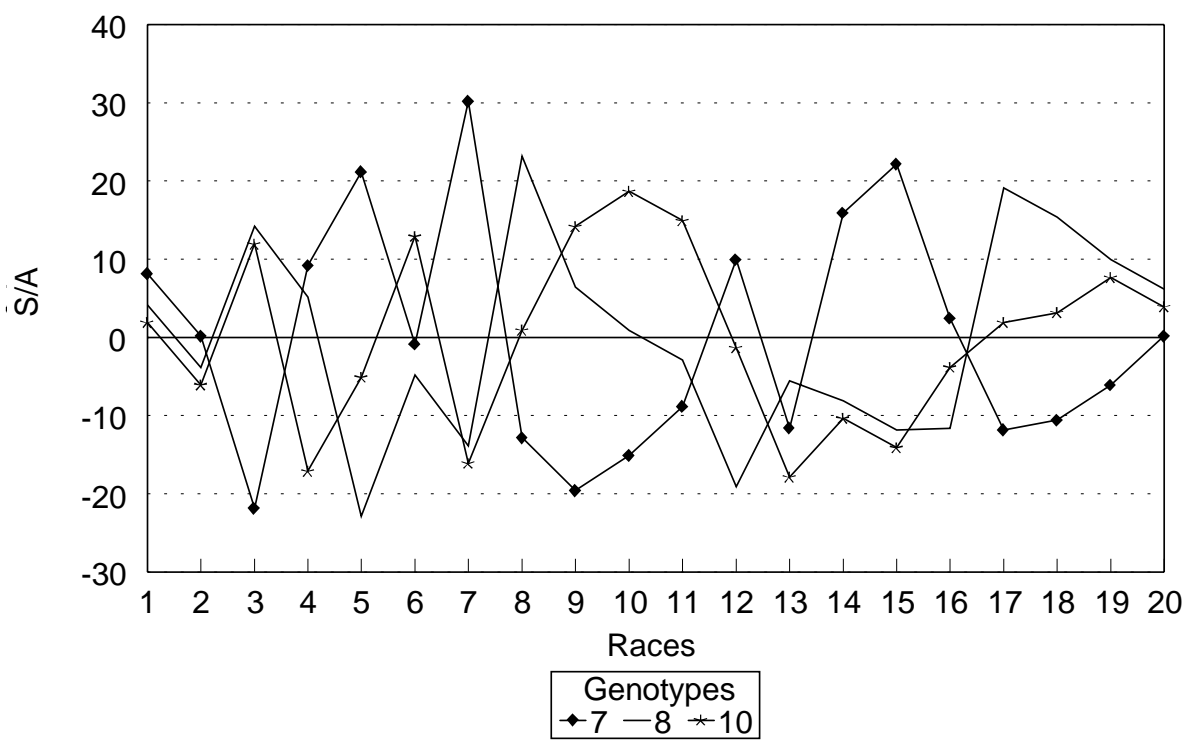

Figure 2 - Specific interaction ability (SIA) of some hosts inoculated with different pathogen races according to interactive model.

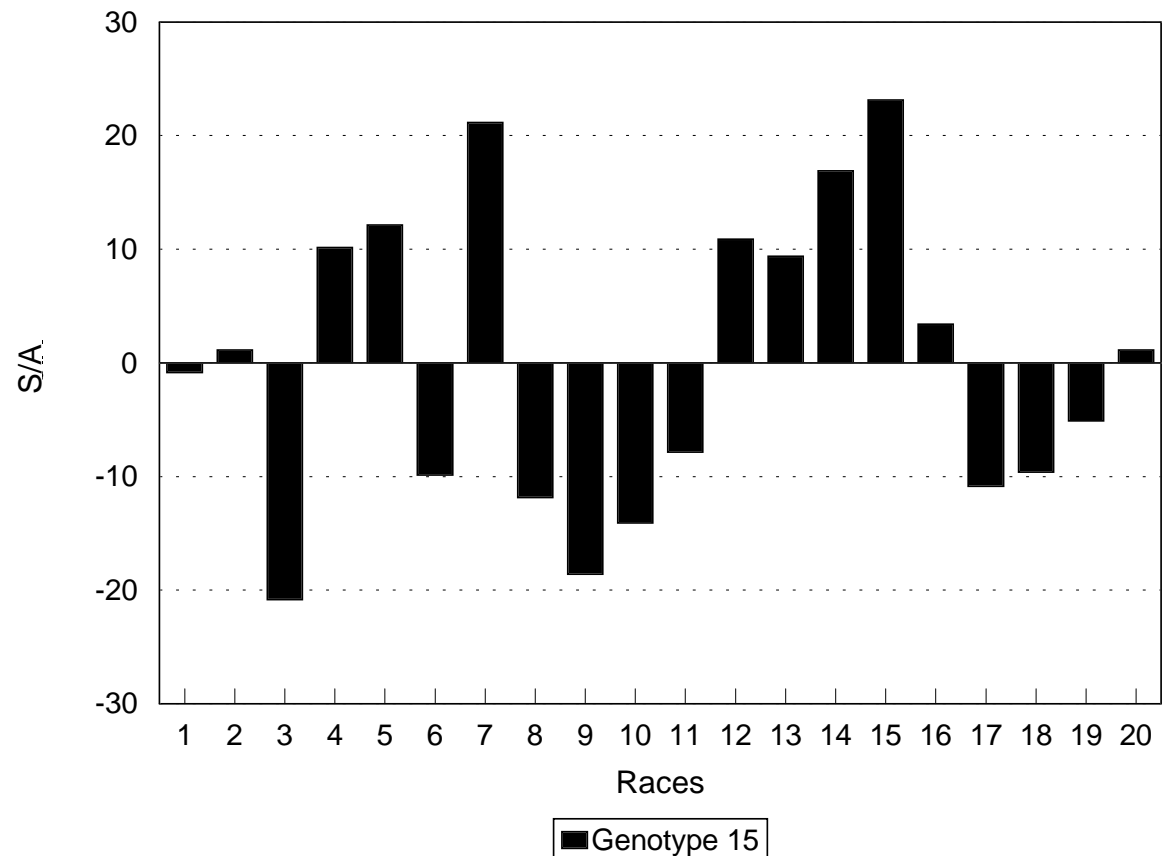

Figure 3 - Specific interaction ability (SIA) of host 15 inoculated with different pathogen races according to interactive model. 
Table $\mathbf{X}$ - Correlations between general reaction ability (GRA) estimates from different numbers of races infecting the 20 hosts, according to additive and interactive models.

\begin{tabular}{|cccccccc|}
\hline & \multicolumn{3}{c}{ Additive model } & & \multicolumn{3}{c|}{ Interactive model } \\
\cline { 2 - 4 } \cline { 6 - 8 } $20 \times 20$ & $20 \times 10 \mathrm{~F}$ & $20 \times 10 \mathrm{~L}$ & $20 \times 5 \mathrm{~F}$ & & $20 \times 10 \mathrm{~F}$ & $20 \times 10 \mathrm{~L}$ & $20 \times 5 \mathrm{~F}$ \\
& $1.00 * *$ & $1.00 * *$ & $0.982 * *$ & & $0.983 * *$ & $0.984 * *$ & $0.984 * *$ \\
\hline
\end{tabular}

$10 \mathrm{~F}=$ Ten first races $(1$ to 10$), 10 \mathrm{~L}=$ ten last races $(11$ to 20$), 5 \mathrm{~F}=$ five first races $(1$ to 5$)$ from Table I. ** Significant at $1 \%$ level of probability according to $t$-test.

mated (Table X). The high correlations found indicated the validity of the model even when using a smaller number of races, which proves the usefulness of this methodology to study host-pathogen polygenic interaction. This methodology is being successfully used to study Eucalyptus grandis-Puccinia psidii (work under progress), allowing the identification of horizontal and vertical resistance components and facilitating the identification of resistance clones for use in crosses.

\section{CONCLUSIONS}

The partial diallel model is an efficient methodology for assessing host-pathogen interaction and indicating more resistant genotypes.

Polygenic resistance has horizontal and vertical components, which can be isolated with this methodology.

GRA values are efficient indicators of horizontal host resistance and GAA values indicate pathogen aggressivity.

SIA values are efficient indicators of host vertical resistance and pathogen virulence.

Both interactive and the additive models show pathogen and host interaction. Therefore, it is not caused by only gene for gene interaction.

Study of polygenic host-pathogen interaction using diallel analysis does not need to involve all races corresponding to the hosts. A representative sample of the set of races available can be used.

\section{ACKNOWLEDGMENTS}

The authors thank the Conselho Nacional de Desenvolvimento Científico e Tecnológico (CNPq) and Fundação de Apoio à Pesquisa de Minas Gerais (FAPEMIG).

\section{RESUMO}

A resistência de plantas a patógenos é a forma mais viável de controle de doenças. No entanto, a identificação de genótipos resistentes muitas vezes é difícil, principalmente pelo desconhecimento da relação patógeno-hospedeiro. O objetivo desse trabalho foi testar uma metodologia que conseguisse, de maneira simples, informar sobre a resistência vertical e horizontal dos hospedeiros e também sobre a agressividade e virulência dos patógenos. Para isso foi realizada uma simulação utilizando vinte, dez e cinco raças do patógeno e vinte hospedeiros. A reação do hospedeiro era controlada por 10 genes com 2 alelos cada. Desses genes, 8 eram de pequeno efeito, 1 de médio e 1 de grande. No patógeno o controle genético era idêntico ao hospedeiro. Foi considerada na simulação apenas a presença de locos em homozigose, com ausência de epistasia. A simulação baseou-se na severidade de doença esperada com a inoculação dos vinte hospedeiros com as vinte raças do patógeno, segundo os modelos aditivo e interativo (com modificações) propostos por Parlevliet e Zadoks (Euphytica 26: 5-21, 1977). A análise dos dados foi através do modelo IV de Griffing (1956), utilizando o esquema de dialelo parcial. Encontrou-se uma alta correlação entre capacidade geral de reação (GRA) e a resistência horizontal, e também alta correlação entre capacidade geral de agressividade (GAA) e a patogenicidade potencial da raça, mostrando ser indicador da agressividade. A capacidade específica de interação (SIA) revelou-se um indicador da resistência vertical do hospedeiro e da virulência do patógeno. A simulação com número menor de raças (10 e 5) mostrou resultados similares aos obtidos com as 20. Tanto no modelo interativo quanto no aditivo a SIA mostrouse significativa, indicando ser possível a existência da interação patógeno com hospedeiro nos dois modelos.

\section{REFERENCES}

Geraldi, I.O. and Miranda-Filho, J.B. (1988). Adapted models for the analysis of combining ability of varieties in partial diallel crosses. Rev. Bras. Genet. 11: 431-440.

Griffing, B. (1956). Concept of general and specific combining ability in relation to diallel crossing systems. Aust. J. Biol. Sci. 9: 463-493.

Nelson, R.R. (1978). Genetics of horizontal resistance to plant diseases. Ann. Rev. Phytopathol. 16: 359-378.

Parlevliet, J.E. (1993). What is durable resistance, a general outline. In: Durability of Disease Resistance (Jacobs, Th. and Parlevliet, J.E., eds.). Kluwer Academic Publishers, Dordrecht, pp. 23-39.

Parlevliet, J.E. and Zadoks, J.C. (1977). The integrated concept of disease resistance; a new view including horizontal and vertical resistance in plants. Euphytica 26: 5-21.

Robinson, R.A. (1979). Permanent and impermanent resistance to crop parasites; a re-examination of the pathosystem concept with special reference to rice bast. Pflanzenzuchtg 83: 1-39.

Vanderplank, J.E. (1968). Disease Resistance in Plants. Academic Press, New York

(Received March 19, 1998) 